\title{
Screening of acromegaly in adults with obstructive sleep apnea: is it worthwhile?
}

\author{
Pierre Attal ${ }^{1} \cdot$ Philippe Chanson $^{2}$
}

Received: 23 April 2018 / Accepted: 24 April 2018 / Published online: 22 May 2018

(c) Springer Science+Business Media, LLC, part of Springer Nature 2018

The prevalence of obstructive sleep apnea (OSA) is very high in the general population (i.e., between the ages of 50 and 70 years, it is around 61 and $37 \%$, in men and women, respectively). It is dependent essentially on age, sex and body mass index [1]. There has been a dramatic increase in the incidence of OSA over the last decades, mostly attributed to an epidemic of obesity $[1,2]$. Conversely, the prevalence of acromegaly is very low, ranging from 2.8 to 13.7 cases per 100,000 [3]. This comparative rarity is probably one of the reasons why its diagnosis is challenging and often made only after a delay of many years [3], and due to the very gradual and progressive installation of the dysmorphic syndrome which is characteristic of the disease [4]. According to various (mostly cross-sectional) studies [5-15], OSA affects a majority of patients with acromegaly: on average, OSA, as assessed by polysomnography, is found in $69 \%$ of patients with active acromegaly [16] and contributes to a great extent to fatigue in these patients. After effective treatment of acromegaly, either surgical or medical, OSA improves in many patients but may persist in $40 \%$ of them $[16,17]$. Every patient with acromegaly thus needs to be checked for OSA at least after treatment of their acromegaly, if possible using polysomnography or, eventually, by home (ambulatory) sleep apnea testing [18].

The facial skeletal deformities (particularly of the mandible), and pharyngeal and tongue modifications

Philippe Chanson

philippe.chanson@bct.aphp.fr

1 Department of Otolaryngology and Head and Neck Surgery, Shaare-Zedek Medical Center, The Hebrew University Medical School, Jerusalem, Israel

2 Service d'Endocrinologie et des Maladies de la Reproduction and Centre de Référence des Maladies Endocriniennes Rares de l'Hypophyse, Assistance Publique-Hôpitaux de Paris, Hôpitaux Universitaires Paris-Sud, Hôpital de Bicêtre \& UMRS 1185, Fac Med Paris Sud, Université Paris-Saclay, Le Kremlin-Bicêtre F-94276, France associated with acromegaly are the major determinants of OSA [9]. However, these anatomical changes are not sufficient to cause OSA, as thickening of soft tissue also plays a major role in the occurrence of OSA in this setting [19]. Generalized soft-tissue thickening is a well-known feature of acromegaly and is related to glycosaminoglycan deposition and increased collagen production by connective tissue, but is also related to tissue edema. Tissue edema is due to increased renal sodium reabsorption by the distal tubules in the kidney, owing to direct stimulation of epithelial sodium channels by GH and IGF-I [20-22]. Overweight, associated with acromegaly in some patients, may also play a major role. This may explain the variable reversibility of OSA after effective treatment for acromegaly [17]. Finally, a role of altered neuromuscular control of the pharyngeal muscles cannot be ruled out. Indeed, in an animal model of acromegaly, we observed myopathy of a dilator muscle of the pharynx [23].

As acromegaly is rare, every means leading to a reduction in the long (5-10 years in general) diagnostic delay would be highly desirable. In this setting, one could ask the question whether it might therefore be worthwhile screening all patients with OSA for acromegaly?

In this issue of the Journal, Heinrich et al. [24] have attempted to answer this question by performing a prospective cross-sectional diagnostic study in patients with OSA. By measuring IGF-I in 507 patients with a confirmed diagnosis of OSA, they found 10 patients with increased IGF-I levels, among whom only one did not show suppression of GH under oral glucose tolerance test and had a microadenoma on pituitary MRI, confirming the diagnosis of acromegaly and giving an acromegaly prevalence of $0.2 \%$ among this OSA cohort. These results confirm those of a recent French multicenter study, reported by Galerneau et al [25], where a very similar prevalence of acromegaly was found in a comparable group of subjects with OSA. It is interesting to note that, in the end, these results on real populations corroborate the results that would be predicted taking into account the known prevalence of acromegaly in 
the general population and that of OSA in acromegalic patients.

The authors conclude that, even if the risk of having acromegaly is increased 8-30-fold in patients with OSA compared to the general population [25], when the very low prevalence of acromegaly is taken into account, screening for this disease by measuring IGF-I in OSA patients provides a poor return. We also need to remember that for adoption of a disease screening procedure, according to the WHO [26], ten criteria should be met:

- The screened condition should represent an important health problem

- There should be an accepted treatment for patients with recognized disease

- Facilities for diagnosis and treatment should be available

- There should be a recognizable latent or early symptomatic stage of the condition

- There should be a suitable test or examination.

- The test should be acceptable to the population.

- The natural history of the condition, including its development from latent to declared disease, should be adequately understood.

- There should be an agreed policy on whom to treat as patients.

- The cost of case-finding (including diagnosis and treatment of patients diagnosed) should be costeffective in relation to possible expenditure on medical care as a whole.

- Case-finding should be a continuous process and not a "once and for all" project.

Though acromegaly may fulfill the requirements of criteria $2,3,5,6$, and $8 \ldots$ it is much more questionable for the remaining criteria...

If systematic screening even in selected populations is not worthwhile, how can we then improve the diagnosis of acromegaly? It is likely that teaching physicians to maintain a high degree of clinical awareness for recognizing the signs and symptoms of acromegaly, not only in OSA patients but also in the general population, remains the best approach. This is quite a difficult task not only in the case of acromegaly but also for all rare diseases. Indeed, each specialist in a rare disease wants to improve the diagnosis of "his/her" rare disease, forgetting that all the other specialists in other rare diseases have the same preoccupation. Furthermore, it is impossible to achieve this in the case of "normal" general physicians in particular because of the high probability that they will never (or, at most, once..!) come across such a patient with these rare diseases during their career!

For this objective, computers may provide better assistance than continuing to teach the few medical students who still attend lectures and showing them pictures of acromegalic patients. Indeed, acromegaly can now be detected by computer software using facial photographs, more accurately than by medical experts or general internists, particularly in patients showing mild features of acromegaly [27]. Additionally, artificial intelligence with deep learning algorithms appears to be even more powerful, providing up to $96 \%$ sensitivity and specificity [28]. Thus, in screening for acromegaly, rather than sampling for IGF-I assay, it may be better to ask the subject, referred for suspicion of OSA, to show their face to the physician's computer or smartphone, equipped with the necessary software, in order to verify if he/she has acromegaly or not!

\section{Compliance with ethical standards}

Conflict of interest P.C. has received unrestricted research and educational grants from Ipsen, Novartis and Pfizer as Head of the Service d'Endocrinologie et des Maladies de la Reproduction, Hôpitaux Universitaires Paris-Sud, he has served as investigator (principal or coordinator) for clinical trials funded by Novartis, Pfizer, Ipsen, Italpharmaco and Antisense, he is member of Advisory Boards from Ipsen, Novartis and gave lectures for Ipsen, Novartis, and Pfizer; All the fees and honoraria are paid to his Institution. The remaining author declares that he has no conflict of interest.

\section{References}

1. P.E. Peppard, T. Young, J.H. Barnet, M. Palta, E.W. Hagen, K.M. Hla, Increased prevalence of sleep-disordered breathing in adults. Am. J. Epidemiol. 177(9), 1006-1014 (2013). https://doi.org/10. 1093/aje/kws342

2. K.A. Franklin, E. Lindberg, Obstructive sleep apnea is a common disorder in the population-a review on the epidemiology of sleep apnea. J. Thorac. Dis. 7(8), 1311-1322 (2015). https://doi.org/10. 3978/j.issn.2072-1439.2015.06.11

3. P. Petrossians, A.F. Daly, E. Natchev, L. Maione, K. Blijdorp, M. Sahnoun-Fathallah, R. Auriemma, A.M. Diallo, A.L. Hulting, D. Ferone, V. Hana, Jr., S. Filipponi, C. Sievers, C. Nogueira, C. Fajardo-Montanana, D. Carvalho, V. Hana, G.K. Stalla, M.L. Jaffrain-Rea, B. Delemer, A. Colao, T. Brue, S. Neggers, S. Zacharieva, P. Chanson, A. Beckers, Acromegaly at diagnosis in 3173 patients from the Liege Acromegaly Survey (LAS) Database. Endocr. Relat. Cancer 24(10), 505-518 (2017). https://doi. org/10.1530/ERC-17-0253

4. P. Chanson, S. Salenave, P. Kamenicky, Acromegaly. Handb. Clin. Neurol. 124, 197-219 (2014). https://doi.org/B978-0-44459602-4.00014-9 [pii] 10.1016/B978-0-444-59602-4.00014-9

5. M.V. Davi', L.D. Carbonare, A. Giustina, M. Ferrari, A. Frigo, V. Lo Cascio, G. Francia, Sleep apnoea syndrome is highly prevalent in acromegaly and only partially reversible after biochemical control of the disease. Eur. J. Endocrinol. 159(5), 533-540 (2008)

6. R.R. Grunstein, K.Y. Ho, C.E. Sullivan, Sleep apnea in acromegaly. Ann. Intern. Med. 115(7), 527-532 (1991)

7. T.B. Hart, S.K. Radow, W.G. Blackard, H.S. Tucker, K.R. Cooper, Sleep apnea in active acromegaly. Arch. Intern. Med. 145 (5), 865-866 (1985)

8. B.L. Herrmann, T.E. Wessendorf, W. Ajaj, S. Kahlke, H. Teschler, K. Mann, Effects of octreotide on sleep apnoea and 
tongue volume (magnetic resonance imaging) in patients with acromegaly. Eur. J. Endocrinol. 151(3), 309-315 (2004)

9. W. Hochban, K. Ehlenz, R. Conradt, U. Brandenburg, Obstructive sleep apnoea in acromegaly: the role of craniofacial changes. Eur. Respir. J. 14(1), 196-202 (1999)

10. M.S.M. Ip, K.C.B. Tan, W.C.G. Peh, K.S.L. Lam, Effect of Sandostatin LAR $^{\oplus}$ on sleep apneoa in acromegaly: correlation with computerized tomographic cephalometry and hormonal activity. Clin. Endocrinol. 55, 477-483 (2001)

11. T. Pekkarinen, M. Partinen, R. Pelkonen, M. Iivanainen, Sleep apnoea and daytime sleepiness in acromegaly: relationship to endocrinological factors. Clin. Endocrinol. 27(6), 649-654 (1987)

12. W.H. Perks, P.M. Horrocks, R.A. Cooper, S. Bradbury, A. Allen, N. Baldock, K. Prowse, W. van't Hoff, Sleep apnoea in acromegaly. Br. Med. J. 280(6218), 894-897 (1980)

13. L. Sze, C. Schmid, K.E. Bloch, R. Bernays, M. Brandle, Effect of transsphenoidal surgery on sleep apnoea in acromegaly. Eur. J. Endocrinol. 156(3), 321-329 (2007)

14. F.R.B. van Haute, G.F. Taboada, L.L. Correa, G.A.B. Lima, R. Fontes, A.P. Riello, M. Dominici, M.R. Gadelha, Prevalence of sleep apnea and metabolic abnormalities in patients with acromegaly and analysis of cephalometric parameters by magnetic resonance imaging. Eur. J. Endocrinol. 158(4), 459-465 (2008)

15. V. Weiss, K. Sonka, M. Pretl, S. Dostalova, J. Klozar, P. Rambousek, J. Marek, T. Haas, Prevalence of the sleep apnea syndrome in acromegaly population. J. Endocrinol. Invest. 23(8), 515-519 (2000)

16. P. Attal, P. Chanson, Endocrine aspects of obstructive sleep apnea. J. Clin. Endocrinol. Metab. 95(2), 483-495 (2010).https:// doi.org/jc.2009-1912 [pii] 10.1210/jc.2009-1912

17. A.K. Annamalai, A. Webb, N. Kandasamy, M. Elkhawad, S. Moir, F. Khan, K. Maki-Petaja, E.L. Gayton, C.H. Strey, S. O'Toole, S. Ariyaratnam, D.J. Halsall, A.N. Chaudhry, L. Berman, D.J. Scoffings, N.M. Antoun, D.P. Dutka, I.B. Wilkinson, J. M. Shneerson, J.D. Pickard, H.L. Simpson, M. Gurnell, A comprehensive study of clinical, biochemical, radiological, vascular, cardiac, and sleep parameters in an unselected cohort of patients with acromegaly undergoing presurgical somatostatin receptor ligand therapy. J. Clin. Endocrinol. Metab. 98(3), 1040-1050 (2013). https://doi.org/jc.2012-3072 [pii] 10.1210/jc.2012-3072

18. M. Kapoor, G. Greenough, Home sleep tests for obstructive sleep apnea (OSA). J. Am. Board. Fam. Med. 28(4), 504-509 (2015). https://doi.org/10.3122/jabfm.2015.04.140266

19. S. Dostalova, K. Sonka, Z. Smahel, V. Weiss, J. Marek, D. Horinek, Craniofacial abnormalities and their relevance for sleep apnoea syndrome aetiopathogenesis in acromegaly. Eur. J. Endocrinol. 144(5), 491-497 (2001)

20. P. Kamenicky, A. Blanchard, M. Frank, S. Salenave, A. Letierce, M. Azizi, M. Lombes, P. Chanson, Body fluid expansion in acromegaly is related to enhanced epithelial sodium channel (ENaC) activity. J. Clin. Endocrinol. Metab. 96(7), 2127-2135 (2011). jc.2011-0078 [pii] 10.1210/jc.2011-0078

21. P. Kamenicky, G. Mazziotti, M. Lombes, A. Giustina, P. Chanson, Growth hormone, insulin-like growth factor-1, and the kidney: pathophysiological and clinical implications. Endocr. Rev. 35 (2), 234-281 (2014). https://doi.org/10.1210/er.2013-1071

22. P. Kamenicky, S. Viengchareun, A. Blanchard, G. Meduri, P. Zizzari, M. Imbert-Teboul, A. Doucet, P. Chanson, M. Lombes, Epithelial sodium channel is a key mediator of growth hormoneinduced sodium retention in acromegaly. Endocrinology 149(7), 3294-3305 (2008)

23. P. Attal, V. Claes, S. Bobin, P. Chanson, P. Kamenicky, P. Zizzari, Y. Lecarpentier, Growth hormone excess and sternohyoid muscle mechanics in rats. Eur. Respir. J. 34(4), 967-974 (2009). https://doi.org/09031936.00171808 [pii] 10.1183/09031936.001 71808

24. D.A. Heinrich, C. Reinholz, M. Bauer, A. Tufman, R. Frohner, J. Schopohl, M. Bidlingmaier, R.P. Kosilek, M. Reincke, H.J. Schneider, IGF-1-based screening reveals a low prevalence of acromegaly in patients with obstructive sleep apnea. Endocrine (2018). https://doi.org/10.1007/s12020-018-1538-z

25. L.M. Galerneau, J.L. Pepin, A.L. Borel, O. Chabre, M. Sapene, B. Stach, J. Girey-Rannaud, N. Arnol, R. Tamisier, P. Caron, scientific, c., investigators of the French national sleep apnoea, r.: Acromegaly in sleep apnoea patients: a large observational study of 755 patients. Eur. Respir. J. 48(5), 1489-1492 (2016). https:// doi.org/10.1183/13993003.01229-2016

26. J.M.G. Wilson, G. Jungner, Principles and practice of screening for disease. Public Health Papers, vol. 34. (World Health Organization,Geneva, 1968), pp. 22-473.

27. H.J. Schneider, R.P. Kosilek, M. Gunther, J. Roemmler, G.K. Stalla, C. Sievers, M. Reincke, J. Schopohl, R.P. Wurtz, A novel approach to the detection of acromegaly: accuracy of diagnosis by automatic face classification. J. Clin. Endocrinol. Metab. 96(7), 2074-2080 (2011). https://doi.org/10.1210/jc.2011-0237

28. X. Kong, S. Gong, L. Su, N. Howard, Y. Kong, Automatic detection of acromegaly from facial photographs using machine learning methods. EBioMedicine 27, 94-102 (2018). https://doi. org/10.1016/j.ebiom.2017.12.015 